\title{
PROCESS FLOWCHARTING AND SIMULATION OF HOUSE STRUCTURE COMPONENTS PRODUCTION PROCESS
}

\author{
Haitao Yu \\ Mohamed Al-Hussein \\ Department of Civil and Environmental Engineering \\ University of Alberta \\ Edmonton, Alberta, T6G 2W2, CANADA
}

\author{
Reza Nasseri \\ Landmark Master Builder Inc. \\ 9765-54 Ave. \\ Edmonton, Alberta, T6E 5J4, CANADA
}

\begin{abstract}
Stimulated by the success of management innovation in the manufacturing industry - culminating in lean production, many homebuilders attempt to model the construction process on manufacturing. Currently, much of the focus has been on the use of factory-built structural components, which reflects the inherent characteristics of the residential construction industry that medium and large homebuilders construct high volumes of houses with a similar structure. However, many such attempts failed due to operation management problems. This paper presents a hybrid approach that combines process flowcharting and simulation for helping prefabricators analyze and improve their production process. In the research, the process flowchart and process activity chart are used to identify opportunities for process improvement, and simulation models are built in Simphony, a Special Purpose Simulation (SPS) tool, to do what-if analysis and to predict productivity. The results of this study indicate that process flowcharting coupled with simulation is an effective way to plan process improvement.
\end{abstract}

\section{INTRODUCTION}

In North America, homes are constructed predominantly with the cast-in-place concrete foundation and the "stickbuilt" wood platform-framing structure that have been used for decades. The traditional craft-based site-built process is labor intensive with a long construction time and is difficult to control for product quality. Stimulated by the success of management innovation in manufacturing industry - culminating in lean production, there is growing interest in modeling the construction process on manufacturing (O'Brien et al. 2000 and Winch 2003).

Since 2002, the economy of Alberta, Canada, has experienced a robust economic growth driven by high energy prices and resource development, and this trend is expected to be continuous in the next 10 years. A positive economic environment and continued immigration underpin a strong demand for housing. Meanwhile, the unemployed rate in Alberta is $4 \%$, the lowest level in history. The high market demand and a great shortage in labor motivate many builders to seek innovation that can improve productivity and reduce labor usage. Landmark Master Builder Inc., a major local homebuilder in Alberta, has set up a structure components prefabrication plant that produces the wood frame floors, open wall panels and roofs. This new construction method has shown a remarkable potential to improve productivity and shorten the construction time, but so far does not exhibit convincing advantages over the conventional method in the practice. There are various reasons, but the primary one is related to operations management. The change from conventional site-built to factory-based construction is not simply moving the construction tasks and workers from a job site to a plant; it changes the house structure construction process from a project process to a manufacturing process. Most of the construction managers who have strong background in project management do not have the necessary knowledge and experience in operations management. They fail to establish an effective manufacturing system and can not manage the manufacturing process efficiently. This results in wastes in operation and low productivity.

Motivated by this situation, University of Alberta and Landmark Master Builder Inc. initiated a collaborative research aiming at obtaining a clear understanding of the current house structure components production process and identifying potential improvement measures. In the research, the following strategies were taken in pursuit of the overall goal: (1) Collect the information needed for process flowcharting. (2) Create process flowchart, in collaboration with the prefabrication plant manager. (3) Gather operation data. (4) Build a simulation model based on process flowchart and operation data analysis. (5) Identify opportunities for process improvement. (6) Create a new process flowchart depicting the improved processes. (7) Simulate the new processes to predict improved productivity. 


\section{Yu, Al-Hussein and Nasseri}

\section{PROCESS FLOWCHART}

Any research aims at improving the current processes must start by clearly understanding the present practice. Thus the first step of this research was to collect required information and create a current-state process flowchart. The researchers created process flowchart drafts based on oneon-one interviews with the plant manager and site observation on the shop floor and the erection site. Then, a process flowchart was finalized through a panel interview with stakeholders, including the management of homebuilder (customer), plant manager and superintendent. The type of process flowchart used in this research is the crossfunctional flowchart, which depicts how a work process of an organization cut across several functional units (Krajewski and Ritzman 2005). In the flowchart, each lane is designated for a function unit or entity, and every activity that related to this function unit or entity is depicted in this row. For a complex process, cross-functional flowchart is very helpful to reveal the inner relationship between process activities. Figure 1 is the finalized flowchart of prefab- rication process of house structure components. The function units listed in the chart represent both the work cells on the shop floor and crews responsible for the given function.

\section{SIMULATION MODEL}

Information needed for building a simulation model can be grouped into two categories: (1) process definition, and (2) specification of parameters and variables. Since the process has been clearly defined in process flowcharting, the first step of simulation modeling is to gather actual operation data, such as duration and man-hour usage. The researchers spent one month on the shop floor and house construction sites, tracking the entire fabrication and assembly processes of three semi-detached houses. Housing construction is a long duration process, so motion-based methods, such as time study and predetermined motion-time data system (PMTS) are not suitable for construction work

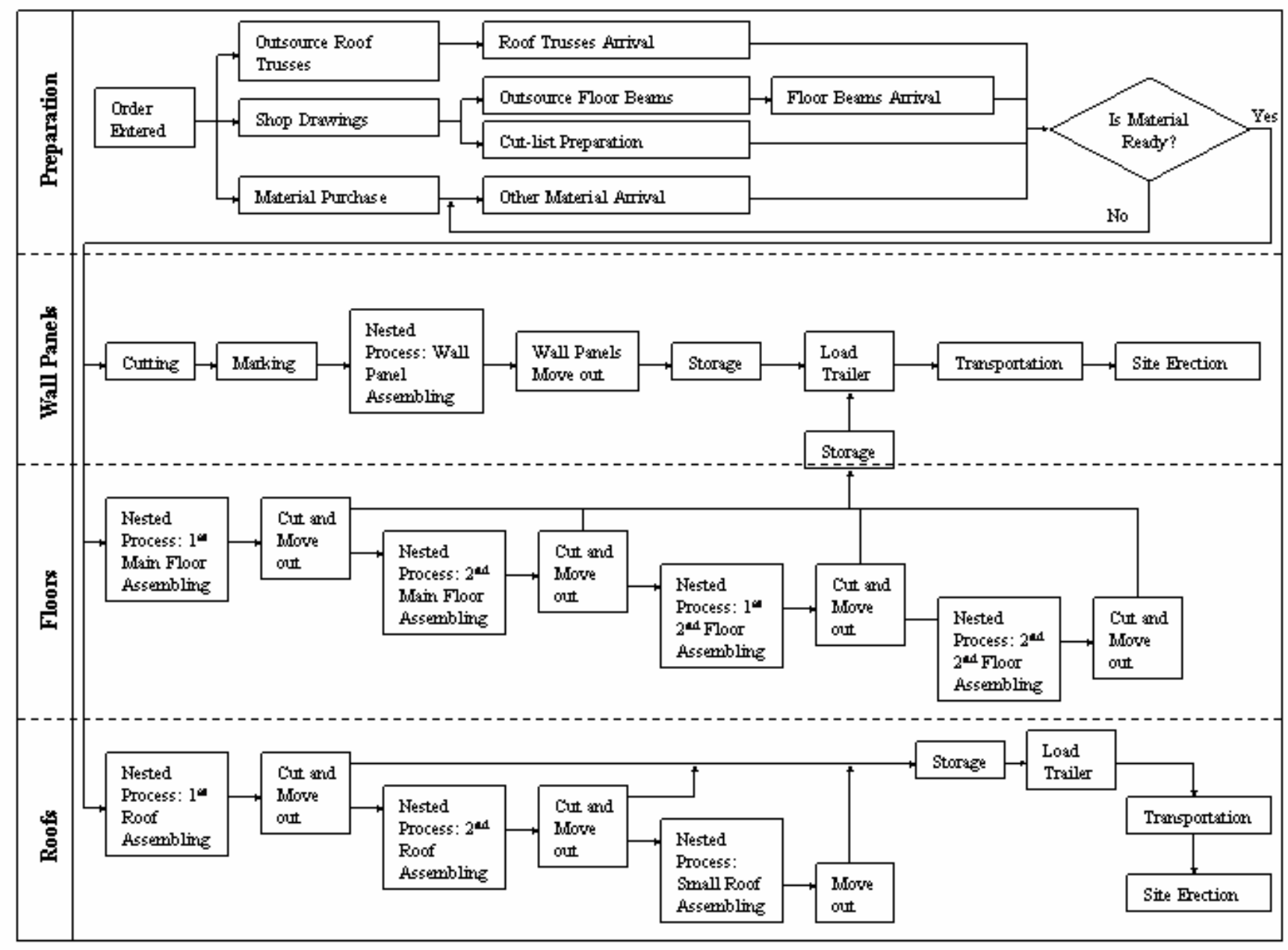

Figure 1: Process flowchart of current house structure components prefabrication process. 


\section{$Y u, A l-H u s s e i n$ and Nasseri}

measurement. Moreover, it is difficult to collect enough data for statistical analysis through site observation. A data processing method is required to reduce the stochastic character caused by small sample size. Data variation can be caused by two kinds of factors; some can be clearly identified and the others are inherent in the process (Chase et al 2006). The objective of data processing is to minimize variation that is caused by definable causes.

Based on above-mentioned considerations, the researchers designed a hybrid sampling method, where the workers' activities is observed in 15 minutes intervals, and the total job time (man-hours) of a given task is derived as in the following equation:

$$
T=\sum_{i=1}^{N} X_{i} \times 0.25 \mathrm{man}-\mathrm{hr}
$$

where $X_{i}=$ number of workers at $i^{\text {th }}$ observation working on the given task; $N=$ number of observations. However, to make this specific time more representative, a technique, named performance rating, is used to "normalize" the job. In fact, during the observation, the researchers also evaluate workers' performance. A normal time can be obtained by including performance rating. In equation form:

$$
N T=T \times I_{s} \times I_{e} \times I_{c 1} \times I_{c 2}
$$

where $I_{s}, I_{e}, I_{c 1}, I_{c 2}$ are performance indexes in terms of skill, effort, condition, and consistency respectively. Table 2 illustrates the corresponding relationship between performance rating and indexes.

After normalization, the job time of tasks of three houses exhibit good consistency except a few outliers caused by occasional reasons, such as material problems. Then, the collected time are averaged to get the standard job time for each activity and duration used in the simulation model is computed by equation:

$$
D=\frac{\text { Average Job Time }}{\text { Average Crew Size }}
$$

Table 1 provides an overview of the job times and durations for all the tasks in house structure components production process.

\section{PROCESS ANALYSIS}

After the completion of process flowchart and the simulation model, the process was analyzed to identify the potential opportunities for improvement. It was found that the current process is a make-to-order process, where production is triggered by receiving booking calls form site managers. By using this strategy, the production is flexible and inventory is kept to minimum, but the lead time would be long and there was no continuous work flow. The simulation result shows that the average lead time of a typical semi-detached house, including erection, is 6.5 workdays

\begin{tabular}{|c|c|c|c|c|}
\hline Task & $\begin{array}{l}\text { Job Time } \\
\text { (man-hr) }\end{array}$ & $\begin{array}{c}\text { Crew } \\
\text { Size }\end{array}$ & $\begin{array}{l}\text { Qty. } \\
\text { /house }\end{array}$ & $\begin{array}{c}\text { Duration } \\
\text { (hr/house) }\end{array}$ \\
\hline Marking & $0.18 /$ panel & 1 & 117 & 21.1 \\
\hline $\begin{array}{ll}\text { Cutting } & \text { for } \\
\text { wall panel } & \end{array}$ & $0.15 /$ panel & 1 & 117 & 17.6 \\
\hline $\begin{array}{l}\text { Making com- } \\
\text { ponents }\end{array}$ & 0.09/panel & 1 & 117 & 10.5 \\
\hline $1^{\text {st }}$ floor wall & $0.5 /$ panel & 2 & 57 & 14.3 \\
\hline $2^{\text {nd }}$ floor wall & $0.4 /$ panel & 2 & 60 & 12.0 \\
\hline Wall move-out & $8.0 /$ house & 2 & 1 & 4.0 \\
\hline $1^{\text {st }}$ Floor & 22.5/piece & 4 & 2 & 11.3 \\
\hline $\begin{array}{l}1^{\text {st }} \text { Floor move- } \\
\text { out }\end{array}$ & 2.0/piece & 6 & 2 & 0.7 \\
\hline $2^{\text {nd }}$ Floor & 23.8/piece & 4 & 2 & 11.9 \\
\hline $\begin{array}{l}2^{\text {nd }} \quad \text { Floor } \\
\text { move-out }\end{array}$ & 3.3/piece & 6 & 2 & 1.1 \\
\hline Main roof & 33.9/piece & 4 & 2 & 17.0 \\
\hline Roof (others) & 19.9/piece & 4 & 1 & 5.0 \\
\hline Roof move-out & 4.1/piece & 6 & 2 & 1.4 \\
\hline $\begin{array}{l}\text { Material mov- } \\
\text { ing }\end{array}$ & $16.3 /$ house & 2 & 1 & 8.2 \\
\hline $\begin{array}{l}\text { Load trailer } \\
\text { (Type1) }\end{array}$ & 4.9/trailor & 2 & 2 & 4.9 \\
\hline $\begin{array}{ll}\begin{array}{l}\text { Load } \\
\text { (Type2) }\end{array} & \text { trailer } \\
\end{array}$ & 5.2/trailor & 2 & 3 & 7.8 \\
\hline $\begin{array}{l}\text { Other activities } \\
\text { in plant }\end{array}$ & 50.0/house & 11 & 1 & 4.5 \\
\hline Transportation & $0.8 /$ trailor & 1 & 5 & 4.0 \\
\hline $\begin{array}{l}\text { Erection prepa- } \\
\text { ration }\end{array}$ & 8.4/house & 4 & 1 & 2.1 \\
\hline $\begin{array}{l}1^{\text {st }} \text { floor erec- } \\
\text { tion }\end{array}$ & 5.0/house & 4 & 1 & 1.3 \\
\hline $\begin{array}{l}1^{\text {st }} \text { floor walls } \\
\text { erection }\end{array}$ & 16.8/house & 4 & 1 & 4.2 \\
\hline $\begin{array}{l}2^{\text {nd }} \text { floor erec- } \\
\text { tion }\end{array}$ & 8.4/house & 4 & 1 & 2.1 \\
\hline $\begin{array}{l}2^{\text {nd }} \text { floor wall } \\
\text { erection }\end{array}$ & 21.8/house & 4 & 1 & 5.5 \\
\hline $\begin{array}{l}\text { Main roof erec- } \\
\text { tion }\end{array}$ & 12.6/house & 4 & 1 & 3.2 \\
\hline $\begin{array}{ll}\text { Other } & \text { roof } \\
\text { erection } & \\
\end{array}$ & 5.9/house & 4 & 1 & 1.5 \\
\hline
\end{tabular}
and the average utilization of floor assembling deck, roof
Table 1: Task job time and durations

assembling deck and wall assembling cell are 37\%, $72 \%$ and $69 \%$ respectively. The observation data supports the simulation result. Figure 2 shows the activity chart of floor deck in the period between June 27 and July 6, 2006. The utilization is $35 \%$.

To achieve low-cost operation, the utilization of facilities must be improved to reduce the fixed cost per unit. A root cause analysis tool - cause-and-effect diagram, was used to find the potential causes for low facility utilization. Based 


\section{Yu, Al-Hussein and Nasseri}

Table 2: Performance index of the Westinghouse rating system (Niebel and Freivalds 1999)

\begin{tabular}{|ll|lr|lr|ll|}
\hline \multicolumn{2}{|c|}{ Skill } & \multicolumn{2}{c|}{ Effort } & \multicolumn{2}{c|}{ Condition } & \multicolumn{2}{c|}{ Consistency } \\
\hline Superskill & +.15 & Excessive & +.13 & Ideal & +.06 & Perfect & +.03 \\
Superskill & +.13 & Excessive & +.12 & Excellent & +.04 & Excellent & +.03 \\
Excellent & +.11 & Excellent & +.10 & Good & +.02 & Good & +.02 \\
Excellent & +.08 & Excellent & +.08 & Average & +.00 & Average & +.00 \\
Good & +.06 & Good & +.05 & Fair & -.03 & Fair & -.03 \\
Average & +.00 & Average & +.00 & Poor & -.07 & Poor & -.04 \\
Fair & -.05 & Fair & -.04 & & & & \\
Fair & -.10 & Fair & -.08 & & & & \\
Poor & -.16 & Poor & -.12 & & & & \\
Poor & -.22 & Poor & -.17 & & & & \\
\hline
\end{tabular}

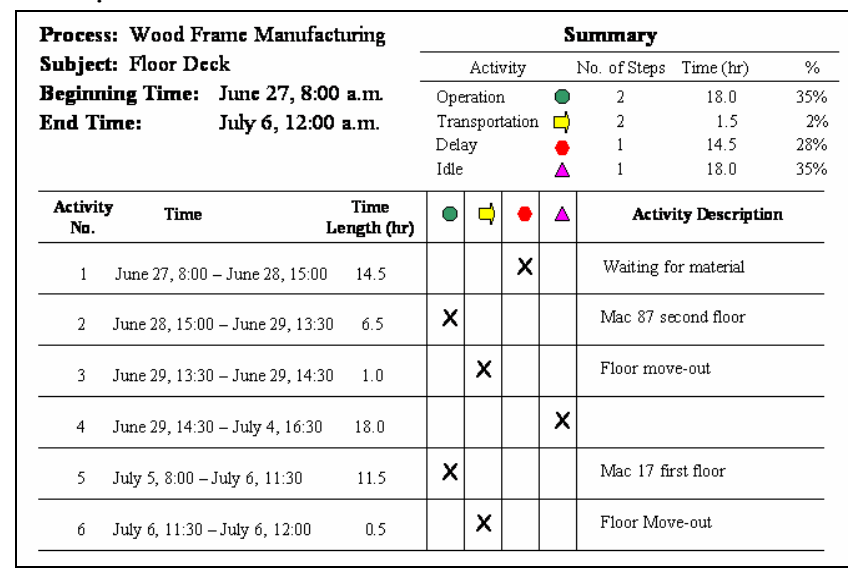

Figure 2: Process activity chart of floor deck

on field observations and one-on-one interviews with plant manager and superintendent, the strongly suspected factors are identified as absentee of key employee, low work efficiency, material not available, and improper manufacturing schedule.

Another process metric measured in process analysis is value-added ratio, which shows how much time really spent on creating value to customer. Figure 3 demonstrates the man-hours used on each tasks. The ratio for valueadded tasks is $67 \%$. Considering that there are also some non-value activities within each task, this ratio is actually much lower. Using the same root cause analysis tool, the main reasons are identified as low morale (long idle time), no job design (no clear definition for each work position), poor facility layout (unnecessary material moving).

\section{PROCESS REDESIGN}

To overcome the problems identified in process analysis, the following solutions are suggested:

- Change the structure of workforce, clarify the job definition, and reorganize the workforce into selfmanagement teams;

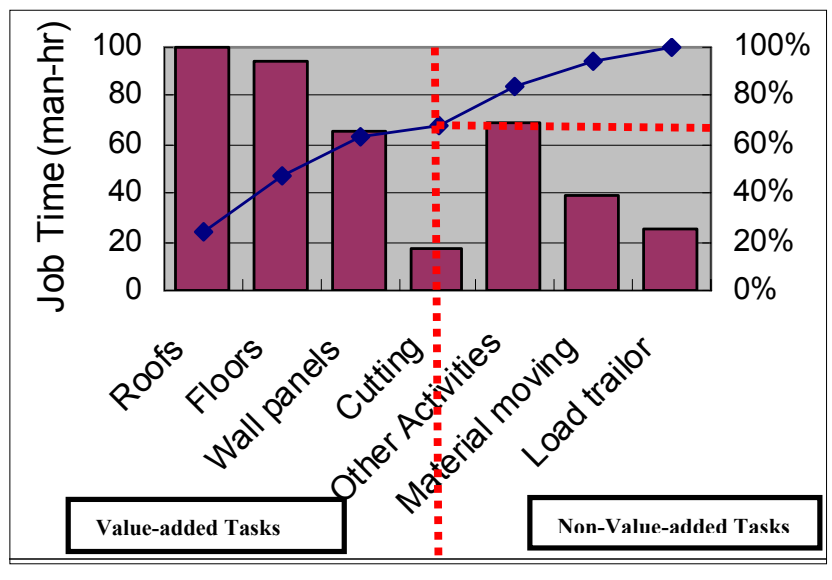

Figure 3: Job time of tasks in prefabrication plant

- Train the specialized workforce to improve the work efficiency;

- Change the process from make-to-order to maketo-schedule, and establish a production schedule system, including monthly master production schedule for resource planning and weekly work plan for job assignment;

- Redesign facility layout to reduce the material movement; and

- Build lasting partnership with suppliers and share the benefits of just-in-time supply;

Figure 4 depicts the modified process flowchart with suggested changes. In a make-to-schedule process, the production in the prefabrication plant is planned according to homebuilder's production schedule. In an ideal situation, the plant can adjust its capacity based on homebuilder's 3month master production schedule. When a monthly look ahead schedule is received, the materials are ordered and shop drawings and cut-list are prepared. After the order is confirmed, the fabrication will be fitted into a weekly working schedule, which is the basis of day-to-day job assignments. By establishing such a schedule system, all the preparation work, including shop drawings and cut-list 


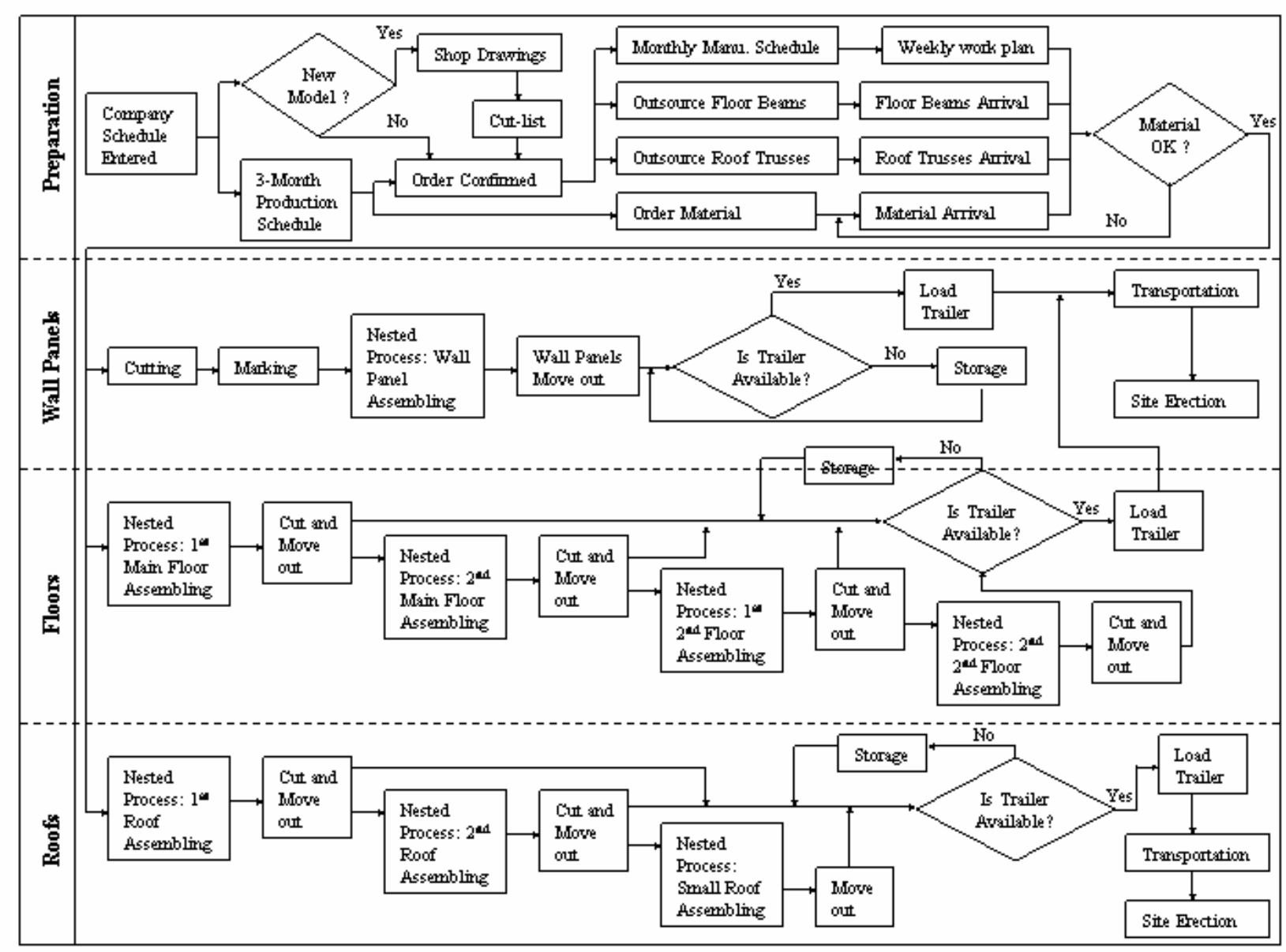

Figure 4: Process flowchart with the suggested changes

preparation, material ordering and trusses outsourcing, can proceed in advance, and the management have more time to response to possible delay and errors in these preparation works. In addition, schedules help to predict and balance the workload of the prefabrication and to adjust the workforce and work plan correspondingly.

\section{PRODUCTIVITY SIMULATION}

One of the advantages of simulation is that once a simulation model has been developed, the analyst can manipulate certain variables to predict the effects of changes on the operating characteristics of interest (Moore and Weatherford 2001). In this research, three scenarios, briefly described below, are selected for illustrating the results of improved house structure components production process.

1. Scenario 1: The house components are fabricated following the improved process. The job time of each task remains the same as that of the current practice, but workforce is restructured to level the production line and time spent on one-off job is stripped.

2. Scenario 2: Job time of each task, except transportation, is shortened by $20 \%$ through implementation of improvement measures suggested by the research team.

3. Scenario 3: The improved house structure components production process has operated for one year, and the job time of each task decreases following standard learning curve. The learning rates are estimated using guidelines proposed by Stewart et al (1995) on task-by-task bases.

A new simulation model is developed in Simphony environment (Hajjar and AbouRizk 1999) based on the process flowchart that includes the suggested changes, as shown in Figure 5, and the main results obtained from simulation is summarized in Table 3. Clearly, in Scenario 1, where the man hour on each job remains same but the workforce is restructured and process is streamlined, the worker productivity increased only $5 \%$, but the throughput 


\section{Yu, Al-Hussein and Nasseri}

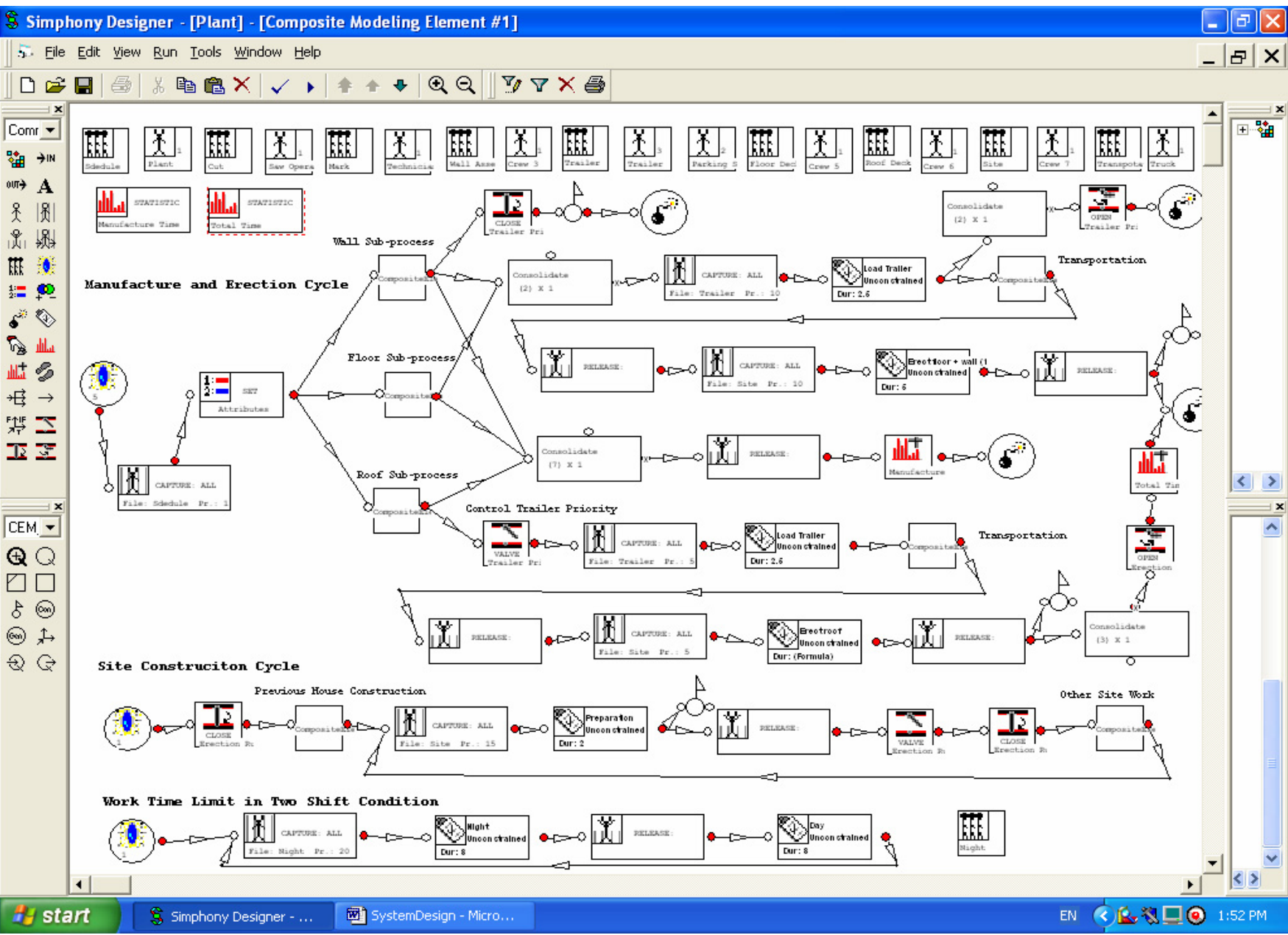

Figure 5: Simulation model in Simphony environment

Table 3: Summary of simulation results

\begin{tabular}{|l|c|c|c|c|c|c|c|c|}
\hline \multirow{2}{*}{$\begin{array}{c}\text { Scenario } \\
\text { Description }\end{array}$} & \multirow{2}{*}{$\begin{array}{c}\text { Workers } \\
\text { Number. }\end{array}$} & \multicolumn{2}{|c|}{$\begin{array}{c}\text { Labor Consumption (per } \\
\text { house) }\end{array}$} & \multicolumn{2}{|c|}{$\begin{array}{c}\text { Throughput Time } \\
\text { (workdays/house) }\end{array}$} & \multicolumn{2}{|c|}{$\begin{array}{c}\text { Throughput Rate (hous- } \\
\text { es/month) }\end{array}$} & \multirow{2}{*}{ Note } \\
\cline { 3 - 8 } & $\begin{array}{c}\text { Man- } \\
\text { hour }\end{array}$ & $\begin{array}{c}\text { Worker } \\
\text { Productivity }\end{array}$ & $\begin{array}{c}\text { Work- } \\
\text { days }\end{array}$ & $\begin{array}{c}\text { Plant } \\
\text { Productivity }\end{array}$ & $\begin{array}{c}20 \text { work- } \\
\text { days/month }\end{array}$ & $\begin{array}{c}30 \text { work- } \\
\text { days/month }\end{array}$ & \\
\hline $\begin{array}{l}\text { Current } \\
\text { Practice }\end{array}$ & $8 \sim 13$ & 485 & $100 \%$ & 6.5 & $100 \%$ & 3.1 & 4.6 & \\
\hline $\begin{array}{l}\text { Scenario } 1 \\
\text { (streamline } \\
\text { process) }\end{array}$ & 18 & 463 & $105 \%$ & 5.0 & $130 \%$ & 4.0 & 6.0 & $\begin{array}{l}\text { Site con- } \\
\text { struction } \\
\text { runs } \\
\text { hours/day }\end{array}$ \\
\hline $\begin{array}{l}\text { Scenario 2 } \\
\text { (reduce job } \\
\text { time by } \\
\text { 20\%) }\end{array}$ & 18 & 394 & $123 \%$ & 3.0 & $217 \%$ & 6.7 & 10.0 & $\begin{array}{l}\text { Improve- } \\
\text { ment goal }\end{array}$ \\
\hline $\begin{array}{l}\text { Scenario 3 } \\
\text { (one year } \\
\text { later) }\end{array}$ & 18 & 298 & $163 \%$ & 2.5 & $260 \%$ & 8.0 & 12.0 & \\
\hline
\end{tabular}




\section{Yu, Al-Hussein and Nasseri}

time is reduced from 6.5 workdays to 5.0 workdays due to the combined effect of the streamlined process and increased crew size. For Scenario 2, the throughput time is further reduced to 3 workdays. This is really important for prefabrication plant management, because cost analysis shows that the breakeven point of the plant is 3 weekdays/house. In other words, in order to achieve breakeven, the production needs to be reorganized based on the suggested process and the productivity of workers needs to be improved by $20 \%$. Scenario 3 estimates the impact of learning on workers' performance. Although the workers' productivity can be dramatically improved by gaining experience, there is only minor improvement in overall plant productivity. This indicates the capacity limit of current production method and facility design.

\section{CONCLUSION}

This work demonstrates the application of process flowcharting and simulation in construction through a detailed example of house structure components prefabrication. The study indicates that process flowchart, along with other process analysis tools, can be effectively used to understand the complex construction process and identify the improvement opportunities. Simulation models are built to expose the existing problems in current process and predict the results of improvement. Since construction is long duration process, a hybrid approach that combines work sampling, performance rating and learning curve theory, is used to collect operation data and construct simulation models. The simulation results motivated the house structure components prefabrication plant to implement the new process and suggested changes.

\section{REFERENCES}

Chase, R. B., Jacobs, F. R. and Aquilano, N. J. 2006. Operations Management for Competitive Advantage, 11th ed. New York: McGraw-Hill/Irwin.

Hajjar, D. and AbouRizk, S.M. 1999. Simphony: An Environment for Building Special Purpose Construction Simulation Tools. Proceedings of the 1999 Winter Simulation Conference, ed. P.A. Farrington, H.B. Nembhard, D.T. Sturrock, and G.W. Evans, 998-1006, Institute of Electrical and Electronics Engineers, Piscataway, New Jersey, USA.

Krajewski, L. J. and Ritzman, L. P. 2005. Operations Management: Processes and Value Chains, 7th ed. Upper Saddle River, New Jersey: Pearson Prentice Hall.

Moore, J. H. and Weatherford, L. R., 2001. Decision Modeling with Microsoft Excel, 6th ed., Upper Saddle River, New Jersey: Prentice-Hall, Inc.

Niebel, B. and Freivalds, A. 1999. Methods, Standards, and Work Design, 10th ed., New York: McGraw-Hill Companies, Inc.
O'Brien, M., Wakefield, R., and Beliveau, Y. 2000. Industrializing the Residential Construction Site, U.S. Department of Housing and Urban Development, Office of Policy Development and Research, Washington, D.C.

Stewart, R. D., Wyskida, R. M. and Johannes, J. D. 1995. Cost Estimator's Reference Manual, 2nd ed., New York: John Wiley \& Sons.

Winch, G. M. 2003. Models of Manufacturing and the Construction Process: the Genesis of Re-engineering Construction. Building Research \& Information, 31(2), 107-118.

\section{AUTHOR BIOGRAPHIES}

HAITAO YU is a doctoral student in the Department of Civil and Environmental Engineering at the University of Alberta since September, 2004. He received his B.E. and M.E. degree in Civil Engineering from Tsinghua University, Beijing, China. His research interest lies in the area of production home building, lean construction, management information system, and computer simulation. His e-mail address is $<$ hyueualberta.ca $>$

MOHAMED AL-HUSSEIN is an assistant professor in the Hole School of Construction Engineering and Management at the University of Alberta. He received B.Sc. and M.Sc. from University of Architecture and Civil Engineering, Sofia, Bulgaria. He completed his Ph.D. studies at Concordia University, Montreal, Canada. His research interest lies in the area of computer modeling with regards to business process modeling and data modeling in construction, including utilization of 3D-solids CAD modeling, objective oriented methodology, and information management systems. His web page can be found via <www. uofaweb. ualberta.ca/construction/a lhussein.cfm>.

REZA NASSERI is the president of Landmark Master Builder Inc. His interests include business strategy, supply chain management, lean construction, computer-based scheduling system and related techniques. He has extensive experience in residential construction and production process planning and management. His e-mail address is $<r e-$ zanelandmarkmasterbuilder.com> 